\title{
The influence of dental care associated with laser therapy on oral mucositis during allogeneic hematopoietic cell transplant: retrospective study
}

\author{
Influência dos cuidados odontológicos acompanhados de laserterapia sobre a mucosite oral \\ durante transplante alogênico de células hematopoiéticas: estudo retrospectivo
}

\author{
Fernanda de Paula Eduardo ${ }^{1}$, Letícia Mello Bezinelli ${ }^{1}$, Mariane Couto Estácio Orsi ${ }^{2}$, Morgani Rodrigues ${ }^{1}$, \\ Martha Simões Ribeiro ${ }^{2}$, Nelson Hamerschlak ${ }^{1}$, Luciana Correa ${ }^{3}$
}

\begin{abstract}
Objective: To verify decrease in frequency and severity of oral mucositis in patients submitted to dental care and laser therapy during allogeneic hematopoietic cell transplant. Methods: Medical records of patients submitted or not to dental care associated with laser therapy during allogeneic transplant were reviewed. The following data were collected: sex, age, underlying disease, myeloablative conditioning regimens, prophylaxis for graft versus host disease, extension and severity of oral mucositis, pain in the oral cavity and when swallowing, diarrhea, need of peripheral parenteral nutrition and presence of acute graft versus host disease. Results: Significant reduction in extension and severity of oral mucositis, as well as in frequency of oral cavity pain, was observed in patients with dental care/laser therapy $(p<0.01)$. There were no statistically significant differences regarding frequency of diarrhea, pain when swallowing, and need of parenteral nutrition among the groups. Significant association was found between acute graft versus host disease and pain when swallowing $(p<0.01)$. Acute graft versus host disease was not associated with oral mucositis severity, oral cavity pain, and diarrhea. Conclusion: Dental care associated with laser therapy reduces the extension and severity of oral mucositis in patients with allogeneic hematopoietic transplant. Further studies are necessary to clarify the isolate efficacy of laser therapy in these conditions, mainly regarding the influence of reduced oral mucositis on the graft versus host disease.
\end{abstract}

Keywords: Oral health; Bone marrow transplantation; Stomatitis; Graft vs host disease

\section{RESUMO}

Objetivo: Verificar a redução da frequência e da gravidade de mucosite oral nos pacientes submetidos a cuidados odontológicos e à laserterapia durante transplante alogênico de células hematopoiéticas. Métodos: Foram analisados retrospectivamente prontuários de pacientes transplantados, com e sem atendimento odontológico acompanhado de laserterapia, coletando-se as seguintes informações: sexo, idade, doença de base, regime mieloablativo e profilático para doença do enxerto contra o hospedeiro, extensão e gravidade de mucosite oral, sintomatologia dolorosa na cavidade oral e para deglutir, diarreia, necessidade de nutrição parenteral periférica e presença de doença do enxerto contra o hospedeiro aguda. Resultados: Houve redução significativa da extensão e da gravidade de mucosite oral, bem como de dor na cavidade oral, nos pacientes com atendimento odontológico/laserterapia $(p<0,01)$. Não se observaram diferenças estatisticamente significantes entre as frequências de diarreia, dor para deglutir e necessidade de nutrição parenteral entre os grupos de pacientes. Houve associação significativa entre doença do enxerto contra o hospedeiro aguda e dor para deglutir $(p<0,01)$; para gravidade de mucosite oral, dor na cavidade oral e diarreia, essa associação não foi observada. Conclusão: 0 atendimento odontológico acompanhado de laserterapia reduziu a extensão e a gravidade de mucosite oral nos pacientes com transplante alogênico de células hematopoiéticas. Mais estudos são necessários para elucidar a eficácia isolada da laserterapia nessas condições clínicas, principalmente com relação à influência dessa redução de mucosite oral sobre a doença do enxerto contra o hospedeiro.

Descritores: Saúde bucal; Transplante de medula óssea; Estomatite; Doença do enxerto-hospedeiro

\footnotetext{
Study carried out at Hospital Israelita Albert Einstein - HIAE - São Paulo, Brazil.

${ }^{1}$ Hematology and Bone Marrow Transplantation, Hospital Israelita Albert Einstein - HIAE - São Paulo, Brazil.

2 Professional Master Program in Laser Dentistry, IPEN-CENEN/SP at Universidade de São Paulo - USP - São Paulo (SP), Brazil.

${ }^{3}$ Department of General Pathology, College of Dentistry at Universidade de São Paulo - USP - São Paulo (SP), Brazil.

Corresponding author: Fernanda de Paula Eduardo - Rua Alves Guimarães, 462, $1^{\circ}$ andar - CEP: 05410-000 - São Paulo (SP), Brasil - Tel.: $3085-2002$ - e-mail: fpeduard@einstein.br

The authors declare there is no conflict of interest.

Received: May 10, 2010 - Accepted: Oct 11, 2010
} 


\section{INTRODUCTION}

Oral complications due to high doses of chemotherapy and radiation therapy during the hematopoietic stem cell transplantation (HSCT) cause high morbidity and can affect transplant success. Oral mucositis (OM) is one of the complications with the highest impact on the medical and economic success of $\operatorname{HSCT}^{(1)}$. The rupture of the oral cavity's epithelial defense due to the cytotoxic effect of the myeloablative regimen, together with the submucosal involvement, leads to several clinical events, such as opportunistic infections, pain, and difficulties in mastication and swallowing. This can result in severe nutritional deficiencies requiring parenteral nutrition and more hospitalization. Furthermore, the high severity of OM and longer hospital stay were associated with higher risk of graft versus host disease (GVHD) ${ }^{(2)}$. All these factors significantly affect the patient's quality of life and increase hospital costs.

Amongst the medical risk factors for OM, the most clinically important are being very young or elderly, female $^{(3)}$, the type of transplant and myeloablative regimen. Regarding the type of transplant, there is evidence that patients submitted to allogeneic transplant develop OM more frequently and of a more severe nature than autologous transplant patients. About $75 \%$ of allogeneic patients will show severe $\mathrm{OM}^{(4)}$. This is due to the high chemotherapy doses and the use of drugs, such as methotrexate, to prevent GVHD, but which are highly cytotoxic to the oral mucosa ${ }^{(5)}$. This drug reduces the regenerative capacity of the oral mucosa thereby prolonging the mucositis and increasing its severity ${ }^{(4)}$.

There is no consensus about the most efficient protocol to prevent and treat OM. Several treatments have been tested, including the use of a keratinocyte growth factor as benzydiamine; mouth rinses with antimicrobial drugs, such as non-alcoholic chlorhexidine; and cryotheraphy or laser therapy during chemotherapy ${ }^{(6,7)}$. Regardless of the chosen treatment, monitoring oral hygiene and the state of the oral mucosa is essential to OM control ${ }^{(8)}$. Therefore, the aim of this paper was to retrospectively assess the frequency and severity of OM in patients submitted to allogeneic transplants of hematopoietic stem cells who were seen daily by dental surgeons, while undergoing laser therapy. Results were compared to a group of patients not receiving dental care.

\section{OBJECTIVE}

To verify if frequency and severity of OM decreased with dental care throughout the transplant period.

\section{METHODS}

The method was approved by the Research Ethics Committee of the Hospital Israelita Albert Einstein (HIAE). This was a prospective study assessing two groups of patients at the same hospital but in different periods.

\section{Patients and data collection}

Data were collected from the records of 43 patients from the HIAE who underwent allogeneic HSCT, from 2004 to 2008 . These patients were seen daily by the dental team, according to the following protocol described. The inclusion criteria, based on the medical records, were the presence of reliable data (without ambiguities, erasures, and with complete and standardized records) including males and females of all age groups, and no early death (prior to bone marrow recovery and/or prior to 28 days of the post-infusion period).

Medical records of 19 HSCT patients who did not receive dental care were also selected according to the above inclusion criteria. This second sample included patients with both allogeneic and autologous HSCT seen between the years 2000 and 2003. Autologous transplants were added due to the small number of allogeneic transplants performed before 2004 (only eight patients). These individuals were also assessed as to their myeloablative regimen, and those cases which bore the closest resemblance to allogeneic transplants as to OM risk were selected. Chronological discrepancies of the two samplings were due to the fact that dental care for patients submitted to HSCT has only been obligatory since 2004.

During the pre-transplant period, the data of interest were sex, age, diagnosis of the underlying disease, myeloablative regime, and GVHD prophylaxis. Information on the use of peripheral parenteral medication, the occurrence of diarrhea with negative antimicrobial cultures, as well as oral cavity and oropharyngeal pain was collected after the transplant. Besides this, maximum degree of OM observed up to the time of marrow engraftment was noted. This was based on World Health Organization (WHO) classification ${ }^{(9)}$, and consisted of clinical observation of the oral mucosa and oropharynx and ranking as $0=$ no signs or symptoms; 1 = presence of burning sensation and/ or erythema; 2 = erythema and ulcer but maintaining solid diet; $3=$ confluence of ulcers and need of liquid diet; 4 = confluence of ulcers and need for peripheral parenteral feeding. This data was obtained from the nursing team records.

As to the inclusion criteria particularly on reliability of information, data on presence of acute GVHD, both oral and in other organs, were only collected for the 
patient group in the 2004 to 2008 period, i.e., treated by the dental team and submitted to laser therapy. Data was collected from 31 patients who were followed up until 100 days after transplant.

\section{Dental treatment and laser therapy}

The dental treatment set up consisted of a pre-transplant clinical examination, with the treatment of endodontic and periodontal infectious foci and the instruction to do dental hygiene by brushing and flossing. In the postinfusion period, the patient underwent daily evaluation by a dentist. On this occasion laser therapy was applied using a low intensity laser (InGaAIP, $660 \mathrm{~nm}, 40 \mathrm{~mW}, 4$ to $\left.6 \mathrm{~J} / \mathrm{cm}^{2}\right)^{(10)}$ and irradiating the areas with highest risk of mucositis (bilateral jugal mucosa, lateral edge of the tongue, palate, oral floor and labial mucosa). Dental monitoring together with laser therapy was carried out up to the full recovery of hematopoietic bone marrow, even if there was no sign of mucositis.

The oral mucosa of the group that did not receive dental treatment was evaluated daily by the nursing team, that also recorded information on pain and the degree of OM according to the WHO criteria.

\section{Statistical analysis}

The data on both groups of patients (with and without dental care) were submitted to descriptive statistics, by means of the likelihood ratio test for the joint analysis of multiple categories, $\chi^{2}$ test or Fisher's exact test for small samples. The Mann-Whitney test was used for the measured variables. The data were considered statistically significant for $\mathrm{p}<0.05$.

\section{RESULTS}

\section{Comparison between the groups with and without dental care}

Table 1 contains the general characteristics of patients and of the myeloablative and prophylactic regimen for GVHD. There were no statistically significant differences about age on comparing both groups. There

Table 1. General data on patients and type of myeloablative and prophylactic conditioning for graft versus host disease in both groups studied

\begin{tabular}{|c|c|c|c|}
\hline Characteristics & $\begin{array}{l}\text { With no dental treatment/with } \\
\text { no laser therapy }(n=19)\end{array}$ & $\begin{array}{c}\text { With dental treatment/with } \\
\text { laser therapy }(n=43)\end{array}$ & p value \\
\hline Age - median (minimum- maximum) & $38(6-54)$ & $36(1-76)$ & 0.897 \\
\hline Sex & & & 0.043 \\
\hline Female (\%) & 26.3 & 53.5 & \\
\hline Underlying disease (\%) & & & $<0.01$ \\
\hline Hodgkin lymphoma & 10.5 & 0.0 & \\
\hline Non-Hodgkin lymphoma & 31.6 & 7.0 & \\
\hline Myelodysplastic syndrome & 15.8 & 7.0 & \\
\hline Other & 15.8 & 18.6 & \\
\hline Myeloablative regimen (\%) & & & $<0.01$ \\
\hline Melphalan and others ${ }^{* *}$ & 5.3 & 9.3 & \\
\hline Others ${ }^{* * * *}$ & 5.3 & 14.0 & \\
\hline Prophylaxis for GVHD (\%) & & & $<0.01$ \\
\hline Cyclosporine & 15.8 & 0.0 & \\
\hline Methotrexate & 0.0 & 14.0 & \\
\hline Methotrexate + tacrolimus & 0.0 & 51.2 & \\
\hline Methotrexate + cyclosporine & 31.6 & 2.3 & \\
\hline Mycophenolate mofetil + cyclosporine & 5.3 & 18.6 & \\
\hline Tacrolimus + cyclosporine & 0.0 & 2.3 & \\
\hline No prophylaxis & 47.4 & 0.0 & \\
\hline No information available & 0.0 & 11.6 & \\
\hline
\end{tabular}


is a significantly higher frequency of women in the group with dental treatment and laser therapy. There also were also significant differences between the two groups as to underlying disease, myeloablative regime and GVHD prophylaxis. In the group without dental treatment there was a predominance of acute myeloid leukemia and non-Hodgkin lymphoma patients, while the group with dental treatments had a predominance of acute myeloid leukemia and acute lymphoid leukemia. Despite significant differences between both groups as to the myeloablative regimen, the higher frequency of conditioning for both groups was observed in cyclophosphamidewithotherchemotherapeuticalagents or total body radiation, as well as in the combination of busulphan/cyclophosphamide or of busulphan/ other agents. Concerning prophylaxis for GVHD, the predominance of methotextrate + cyclosporine for the group without dental treatment and methotrexate + tacrolimus for the group with dental treatment was observed.
Table 2 shows the data observed in the postinfusion period, recorded up to the moment of marrow engraftment. Statistically significant differences are found for the OM days, OM degree and the presence of pain in the oral cavity. The number of days with OM was greater for the group without dental treatment than for those with dental treatment, and there was a greater frequency of III and IV degree of mucositis, that is, severe OM. There were no differences between both groups as to the need for peripheral parenteral nutrition or presence of diarrhea or pain when swallowing.

\section{GVHD in the group with dental treatment}

Table 3 contains the data on acute GVHD observed in patients who received dental treatment, totaling up 31 patients undergoing allogeneic transplant. Of these, $11(35.5 \%)$ showed no GVHD up to the moment of marrow engraftment, $4(12.9 \%)$ showed it only in the oral cavity, $14(45.2 \%)$ only on other organs and two

Table 2. Data on oral mucositis, peripheral parenteral nutrition, diarrhea with negative antimicrobial culture and pain in oral cavity/oropharynx in the post-infusion period of hematopoietic stem cells up to bone marrow engraftment

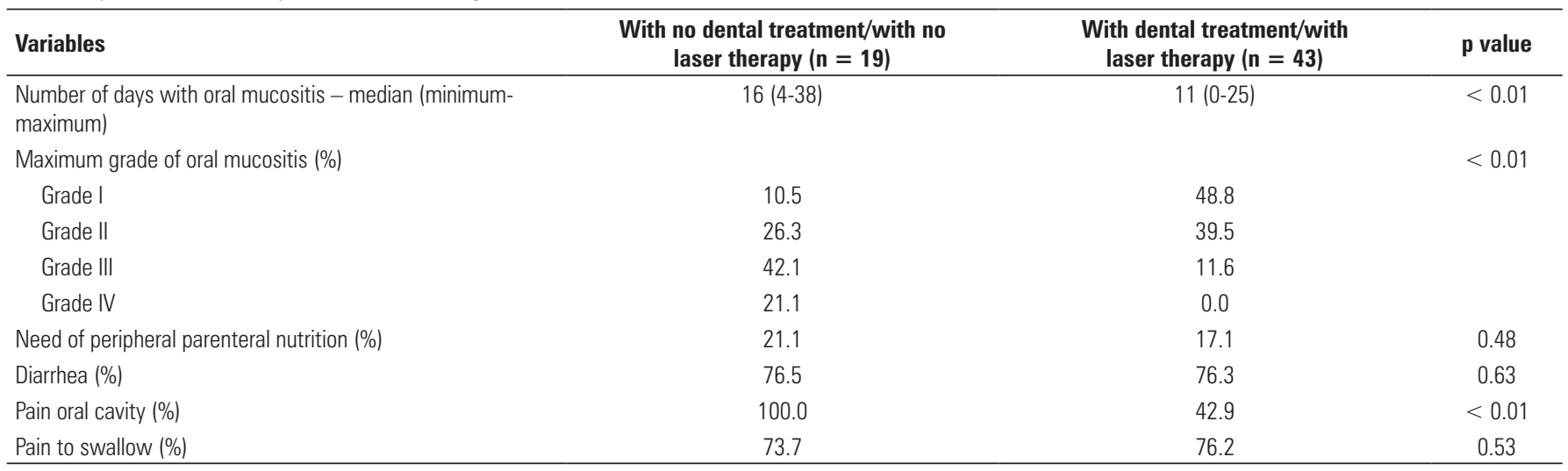

Significant when $p<0.05 ;$ Mann-Whitney, $\chi^{2}$ and Fisher exact tests.

Table 3. Data on acute graft versus host disease in oral cavity or in other organs, regarding oral mucositis and pain in oral cavity or pain upon swallowing

\begin{tabular}{|c|c|c|c|c|}
\hline Variables & Oral GVHD $(\mathrm{n}=6)^{*}$ & p value & GVHD in other organs $(n=16)^{*}$ & p value \\
\hline Number of days with oral mucositis - median (minimum-maximum) & $11.5(3-14)$ & 0.56 & $9(0-17)$ & 0.25 \\
\hline Grade of mucositis $(\%)^{* *}$ & & 0.29 & & 0.36 \\
\hline Grade I & 50.0 & & 56.3 & \\
\hline Grade II & 16.7 & & 37.5 & \\
\hline Grade III & 33.3 & & 6.3 & \\
\hline Pain in the oral cavity (\%) & & 0.13 & & 0.41 \\
\hline Pain to swallow (\%) & & 0.57 & & $<0.01$ \\
\hline Yes & 66.7 & & 93.8 & \\
\hline No & 33.3 & & 6.3 & \\
\hline Diarrhea & & 0.17 & & 0.14 \\
\hline Yes & 33.3 & & 75.0 & \\
\hline
\end{tabular}

Significant when $p<0.05$; Mann-Whitney, $\chi^{2}$ and Fisher exact tests.

* The total sample comprised 31 patients, and 11 did not present acute GVHD in any site and two had GVHD in the oral cavity and other organs; ${ }^{* *}$ no grade IV was observed.

GVHD: graft versus host disease. 
$(6.5 \%)$ showed GVHD both in the oral cavity and other organs. No significant differences were noted when comparing the acute GVHD frequencies with days of mucositis and mucositis severity. Regarding symptoms, significant differences were found only between acute GVHD in other organs and pain upon swallowing.

\section{DISCUSSION}

This study aimed to retrospectively compare severity of OM between two populations submitted to HSCT at the same hospital but at different times. It was observed that patients who received dental treatment and laser therapy had a significant reduction in severity and duration (number of days) of $\mathrm{OM}$ as compared to patients without such care. This decrease resulted in significant less pain in the oral cavity, which has positive consequences to the patients' quality of life. In other words, the rates obtained here both as to OM and esophageal and gastrointestinal mucositis are very similar to those described in literature without dental treatment ${ }^{(2,4,11)}$.

The dental treatment protocol described in this study included not only monitoring of oral hygiene and control of opportunistic infections with antimicrobial drugs, but also the laser therapy, the efficiency of which in the prevention and treatment of OM has been described in various prospective and retrospective clinical studies $^{(10,12,13)}$. Low power laser therapy has a localized analgesic activity, similar to that of cyclooxygenaseinhibiting anti-inflammatory drugs ${ }^{(14)}$. At the same time, laser improves the tissue repairing process, mainly because it stimulates reepithelialization, new collagen deposits, and angiogenesis ${ }^{(15)}$. These laser therapy properties may have contributed to reducing severity of the lesions and pain symptoms.

Close observation of the results shows that in nonulcerated lesions (I and II) there was stability in the mucositis degree of severity throughout the transplant period, as well as a lower number of days of mucositis. The daily laser application protocol at a higher dose, when compared to the literature may have been responsible for this result. Some studies showed that the oral mucosa does not loose its capacity for renovation during mucositis and cell loss is compensated by peaks of keratinocyte proliferation $^{(16)}$ that is circadian-dependent ${ }^{(17)}$. Low-power laser is a potent stimulator of keratinocyte proliferation and may have enhanced this natural response due to its constant use throughout all phases of mucositis.

The beneficial topical effects of dental care and laser therapy were indirectly confirmed by frequency of esophageal and gastrointestinal mucositis. Pain upon swallowing and diarrhea with a negative culture are considered clinical indications of these injuries and the frequency of both were similar in both groups. There was no direct action of the dental team in these places. This result supports the fact that the context of mucositis prevention and control was the same for both groups, with quite positive results for OM in the group that received dental treatment.

The patients enrolled in this study, regardless of their group, were exposed to cytotoxic agents that are of high risk to develop OM. Some studies showed that cyclophosphamide and busulfan in high doses are directly associated with more severe $\mathrm{OM}^{(3,11)}$. These drugs were used in high doses in the two groups that were studied thereby both groups had similar tendencies to develop OM.

Most patients analyzed were also submitted to high doses of methotrexate, a powerful cytotoxic agent, important for GVHD prevention. In the group receiving dental treatment, $67.5 \%$ of the patients used this drug, versus $31.6 \%$ of the group receiving no dental care. From this viewpoint, the group receiving dental care would be more exposed to the risk for OM compared to the other group. In spite of the trend, the severity of OM was lower in this group, thereby reinforcing even more the benefits of the dentistry protocols used. Alternatives substituting methotrexate in GVDH prevention have been quoted in literature due to the clinical impact of mucositis in HSCT. The use of sirolimus in this context showed less $\mathrm{OM}^{(4)}$.

The analysis of the GVHD frequency showed that there is no association between acute GVHD and the extension/severity of OM. There are indications that there is a close cause/effect relation between OM and acute GVHD. Severe OM for prolonged periods has been linked to a greater incidence of acute GVHD and the existence of GVHD appears to contribute to the permanence of the cytotoxic effects in the oral and gastrointestinal mucosa ${ }^{(2)}$. In this study, the low number of patients, especially acute GVHD cases in the oral cavity, associated to the absence of severe OM may have contributed to not establishing an association between both processes. On the other hand, a significant association between GVHD in other organs and pain upon swallowing was observed. Some studies demonstrated the release of pro-inflammatory cytokines from the gastrointestinal tract causes high rates of acute GVHD and that the rupture of epithelial barrier due to mucositis is an important risk factor ${ }^{(18)}$. Pain upon swallowing, whenever other factors are discarded, is considered a medical sign of esophageal mucositis and, in this sense, this result corroborates literature. However no association was found between GVHD and diarrhea, probably due to the small sample size.

Comparing two populations from different periods cannot be overlooked, since they were subjected to two different treatment contexts. The interval between both 
groups (between 2000 and 2008) may have influenced this analysis since the HSCT evolution over the last 10 years has been enormous. Higher survival rates were obtained in this period due to several factors, amongst which the development of new therapies for the control of hematological diseases, opportunistic infections and $\mathrm{GVHD}^{(19)}$, as well as the establishment of a more specialized mutiprofessional team. Therefore, the best results in controlling $\mathrm{OM}$ in the group with dental treatment are attributed not only to the odontological care itself and laser therapy, but also to a medicalhospital context that favors the great evolution in transplant techniques.

\section{CONCLUSION}

Dental care associated with laser therapy reduces the extension and severity of oral mucositis in patients with allogeneic hematopoietic transplant. Further studies are necessary to clarify the isolate efficacy of laser therapy in these conditions, mainly regarding the influence of reduced oral mucositis on the graft versus host disease.

\section{REFERENCES}

1. Sonis ST. Mucositis: The impact, biology and therapeutic opportunities of oral mucositis. Oral Oncol. 2009;45(12):1015-20.

2. Vokurka S, Steinerova K, Karas M, Koza V. Characteristics and risk factors of oral mucositis after allogeneic stem cell transplantation with FLU/MEL conditioning regimen in context with BU/CY2. Bone Marrow Transplant. 2009;44(9):601-5.

3. Barasch A, Peterson DE. Risk factors for ulcerative oral mucositis in cancer patients: unanswered questions. Oral Oncol. 2003;39(2):91-100.

4. Cutler C, Li S, Kim HT, Laglenne P, Szeto KC, Hoffmeister L, et al. Mucositis after allogeneic hematopoietic stem cell transplantation: a cohort study of methotrexate and non-methotrexate-containing graft-versus-host disease prophylaxis regimens. Biol Blood Marrow Transplant. 2005;11(5):383-8.

5. Silva L, Bussoloti-Filho I. Avaliação dos fatores de risco para mucosite oral em um grupo de pacientes sob terapia de transplante de medula. ACTA ORL/ Técnicas em Otorrinolaringologia. 2007;25(2):104-11.
6. Keefe DM, Schubert MM, Elting LS, Sonis ST, Epstein JB, Raber-Durlacher JE, Migliorati CA, McGuire DB, Hutchins RD, Peterson DE; Mucositis Study Section of the Multinational Association of Supportive Care in Cancer and the International Society for Oral Oncology. Updated clinical practice guidelines for the prevention and treatment of mucositis. Cancer. 2007;109(5):820-31.

7. Raber-Durlacher JE, Elad S, Barasch A. Oral mucositis. Oral Oncol. 2010;46(6):452-6.

8. Peterson DE, Bensadoun RJ, Roila F; ESMO Guidelines Working Group. Management of oral and gastrointestinal mucositis: ESMO Clinical Practice Guidelines. Ann Oncol. 2010;21(Suppl 5):v261-5.

9. World Health Organization. Handbook for Reporting Results on Cancer Treatment. Geneva: World Health Organization; 1979. v. 48. p. 16-7.

10. Eduardo FP, Bezinelli L, Luiz AC, Correa L, Vogel C, Eduardo CP. Severity of oral mucositis in patients undergoing hematopoietic cell transplantation and an oral laser phototherapy protocol: a survey of 30 patients. Photomed Laser Surg. 2009;27(1):137-44.

11. Wardley AM, Jayson GC, Swindell R, Morgenstern GR, Chang J, Bloor R et al. Prospective evaluation of oral mucositis in patients receiving myeloablative conditioning regimens and haemopoietic progenitor rescue. Br J Haematol. 2000;110(2):292-9.

12. Antunes HS, de Azevedo AM, da Silva Bouzas LF, Adão CA, Pinheiro CT, Mayhe $\mathrm{R}$, et al. Low-power laser in the prevention of induced oral mucositis in bone marrow transplantation patients: a randomized trial. Blood. 2007:109(5):2250-5.

13. Genot-Klastersky MT, Klastersky J, Awada F, Awada A, Crombez P, Martinez $M D$, et al. The use of low-energy laser (LEL) for the prevention of chemotherapyand/or radiotherapy-induced oral mucositis in cancer patients: results from two prospective studies. Support Care Cancer. 2008;16(12):1381-7.

14. Ferreira DM, Zângaro RA, Villaverde AB, Cury Y, Frigo L, Picolo G, et al. Analgesic effect of He-Ne $(632.8 \mathrm{~nm})$ low-level laser therapy on acute inflammatory pain. Photomed Laser Surg. 2005;23(2):177-81.

15. de Araújo CEN, Ribeiro MS, Favaro R, Zezell DM, Zorn TM. Ultrastructural and autoradiographical analysis show a faster skin repair in He-Ne laser-treated wounds. J Photochem Photobiol B. 2007:86(2):87-96.

16. Dörr W, Hamilton CS, Boyd T, Reed BR, Denham JW. Radiation-induced changes in cellularity and proliferation in human oral mucosa. Int $\mathrm{J}$ Radiation Oncology Biol Phys. 2002;52(4):911-7.

17. Bjarnason GA, Jordan RC, Wood PA, Li Q, Lincoln DW, Sothern RB, et al. Circadian expression of clock genes in human oral mucosa and skin: association with specific cell-cycle phases. Am J Pathol. 2001;158(5):1793-801.

18. Goldberg J, Jacobsohn DA, Zahurak ML, Vogelsang GB. Gastrointestinal toxicity from the preparative regimen is associated with an increased risk of graft-versus-host disease. Biol Blood Marrow Transplant. 2005;11(2):101-7.

19. de la Morena MT, Gatti RA. A history of bone marrow transplantation. Immunol Allergy Clin North Am. 2010;30(1):1-15. 